\begin{tabular}{|l|l|l|}
\hline \multicolumn{2}{|c|}{ PublisherInfo } \\
\hline \hline PublisherName & $:$ & BioMed Central \\
\hline \hline PublisherLocation & $:$ & London \\
\hline \hline PublisherImprintName & $:$ & BioMed Central \\
\hline \hline
\end{tabular}

\title{
Empiric antifungal therapy in febrile neutropenia
}

\begin{tabular}{|l|l|l||}
\hline \multicolumn{2}{|c||}{ ArticleInfo } \\
\hline \hline ArticleID & $:$ & 4254 \\
\hline \hline ArticleDOI & $:$ & $10.1186 /$ ccf-2000-5119 \\
\hline \hline ArticleCitationID & $:$ & 5119 \\
\hline \hline ArticleSequenceNumber & $:$ & 42 \\
\hline \hline ArticleCategory & $:$ & Paper Report \\
\hline \hline ArticleFirstPage & $:$ & 1 \\
\hline \hline ArticleLastPage & $:$ & 3 \\
\hline \hline & & RegistrationDate : 2000-5-10 \\
\hline ArticleHistory & $:$ & OnlineDate \\
\hline \hline ArticleCopyright & $:$ & Current Science Ltd2000-5-10 \\
\hline \hline ArticleGrants & $:$ & \\
\hline \hline ArticleContext & $:$ & 1305433 \\
\hline \hline
\end{tabular}


Naresh Ramakrishnan, ${ }^{\text {Affl }}$

Aff1 The Royal Melbourne Hospital, Australia

\section{Keywords}

Amphotericin B, antifungal therapy, Aspergillus, Candida, febrile neutropenia, fluconazole, fungal infection

\section{Comments}

Winston et al have done a commendable study in this difficult yet important area. Their study shows promise for the use of intravenous (iv) fluconazole instead of amphotericin B in the empiric therapy of invasive fungal infection in the febrile neutropenic patient, thus avoiding the significant toxicity associated with amphotericin B. There are a few problems with adopting this approach directly into clinical practice. The study only showed a trend towards equivalence and did not reach statistical significance. Also, Aspergillus, a rare but important pathogen in this group, is not affected by fluconazole. Overall, fluconazole appears safer than amphotericin B and is not significantly different in its effectiveness in the empiric treatment of suspected invasive fungal infections in the febrile neutropenic patient.

\section{Introduction}

Invasive fungal infections are on the increase and are a challenge to the clinician. Until recently, there have been very few systemic antifungal agents available. amphotericin B was considered standard treatment, but its well-known side effects have made physicians reluctant to use it. Recently, triazoles have been developed, among them fluconazole, which is available for both oral and intravenous administration and is much better tolerated than amphotericin. This forms the rationale of this trial comparing fluconazole with amphotericin B for the empiric treatment of febrile neutropenics, with suspected invasive fungal infections.

\section{Methods}


- A prospective, randomized unblinded study

- Total of 317 febrile neutropenics (Absolute neutrophil count $<500$ cells $/ \mathrm{mm}^{3}$ )

- Persistent fever $>4$ days duration; undergoing treatment with antibacterial agents

- Fluconazole $800 \mathrm{mg}$ iv on day 1 , followed by $400 \mathrm{mg} /$ day iv or amphotericin B $0.5 \mathrm{mg} / \mathrm{kg} / \mathrm{day}$, with dose increased to $1.0-1.5 \mathrm{mg} / \mathrm{kg} /$ day, if evidence of invasive fungal infection is found

- Response was defined satisfactory if patient was afebrile $\left(<38^{\circ} \mathrm{C}\right)$. No clinical $/$ microbiological incidence of fungal infection

- Mean age 47 years ( $\mathrm{SD} \pm 15$ ) and both groups were well matched for other demographics

\section{Results}

There were equal number of successors ( $68 \%$ vs $67 \%$ ) and failures ( $8 \%$ vs $6 \%$ ) in both arms; however, neither reached statistical significance. The incidence of drug withdrawal due to toxicity was higher in the amphotericin group ( $7 \%$ vs $1 \% ; P=0.005$ ). Interestingly $13 \%$ of the patients treated with the fluconazole needed to have treatment changed to amphotericin B for lack of clinical improvement, as opposed to $2 \%$ treated with amphotericin b $(P<0.001)$.

\section{Additional information}

Candida species are the prominent fungal pathogens, followed by Aspergillus species and occasionally other opportunistic fungi in febrile neutropenics. In patients without neutropenia, fluconazole has been shown to be as effective as amphotericin B in the treatment of Candidemia.

\section{References}

1. Winston DJ, Hawthorn JW, Schuster MG, Schiller GJ, Territo MC: A multicentre, randomized trial of fluconazole versus amphotericin B for empiric antifungal therapy of febrile neutropenic patient with cancer. Am J Med. 2000, 108: 282-289. 